\title{
Kemampuan Komunikasi Matematis Peserta Didik Melalui Soal PISA 2015
}

\author{
Zulfah $^{1}$ *, Wida Rianti ${ }^{2}$ \\ ${ }^{1,2}$ Program Studi Pendidikan Matematika, Universitas Pahlawan Tuanku Tambusai. Jalan \\ Tuanku Tambusai No. 23, Bangkinang 28412, Indonesia. \\ *E-mail: zulfahasni670@gmail.com, Telp: +6281267157303
}

Article received: 06-08-2018, article revised :04-09-2018, article published: 07-09-2018

DOI : 10.25273/jipm.v7i1.3064

\begin{abstract}
Abstrak
Tujuan penelitian ini adalah menganalisis kemampuan komunikasi matematis peserta didik Bangkinang dalam menyelesaikan soal PISA 2015. Indikator kemampuan komunikasi matematis yang dilihat yaitu kemampuan menulis, menggambar, dan mampu membuat ekspresi matematis. Metode penelitian yang digunakan adalah deskripsi kualitatif yaitu menggambarkan mengenai kemampuan komunikasi yang dimiliki peserta didik Bangkinang dalam menyelesaikan soal PISA 2015. Instrumen yang digunakan berupa soal PISA 2015 paket 1. Peserta didik masih kesulitan dalam membuat model matematika dari permasalahan yang diberikan, memilih strategi yang tepat guna memecahkan permasalahan yang diberikan, diikuti dengan rendahnya kemampuan peserta didik merefleksikan grafik ke dalam ide matematika yang mana termasuk kategori drawing. Ringkasan dari analisis ketujuh soal PISA 2015 yang dikategorikan soal Komunikasi Matematis yaitu (1) Written Text, Pada soal nomor $15 ; 10,26 \%$ peserta didik berkemampuan tinggi; 2,56\% berkemampuan sedang; dan 87,18\% berkemampuan rendah. (2) Mathematical Expression, Pada soal nomor 12; 15,38\% peserta didik berkemampuan tinggi; 15,38 peserta didik berkemampuan sedang; dan 69,24\% berkemampuan rendah. (3) Drawing, Pada soal nomor 30; $82,05 \%$ peserta didik berkemampuan tinggi; dan $17,94 \%$ berkemampuan rendah. Berdasarkan penelitian yang telah dilaksanakan pada 39 peserta didik, dapat disimpulkan bahwa kemampuan komunikasi matematis peserta didik SMP di Bangkinang melalui penyelesaian soal PISA 2015 masih rendah pada kategori Mathematical Expression.
\end{abstract}

Kata Kunci: Komunikasi Matematis; soal PISA 2015

\begin{abstract}
The purpose of this study was to analyze the mathematical communication skills of Bangkinang students in completing the 2015 PISA problem. Indicators of mathematical communication skills that were seen were the ability to write, to draw, and to be able to make mathematical expressions. The research method used is a qualitative description, which describes the communication skills possessed by Bangkinang students in completing the 2015 PISA problem. The instrument used is a 2015 PISA package. 1. Students still have difficulties in making mathematical models of the problems given, choosing the right strategy in order to solve the given problem, followed by the low ability of students to reflect the graph into which mathematical ideas belong to the drawing category. A summary of the seventh analysis of the 2015 PISA questions categorized as Mathematical Communication, namely (1) Written Text, in problem number $15 ; 10.26 \%$ of highly skilled students; $2.56 \%$ moderate ability; and $87.18 \%$ low ability. (2) Mathematical Expression, in problem number $12 ; 15.38 \%$ of high-ability students; 15.38 students with moderate abilities; and $69.24 \%$ with low ability. (3) Drawing, in question number 30; $82.05 \%$ of high-ability students; and $17.94 \%$ low ability. Based on the research conducted on 39 students, it can be concluded that
\end{abstract}




\section{JIPM (Jurnal Ilmiah Pendidikan Matematika), 7(1), September 2018- 50}

Zulfah, Wida Rianti

the mathematical communication skills of junior high school students in Bangkinang through the completion of the 2015 PISA problem are still low in the Mathematical Expression category.

Keywords: Mathematical Communication; PISA 2015

\section{PENDAHULUAN}

Komunikasi matematis merupakan satu dari sekian kemampuan yang harus dimiliki oleh peserta didik yang juga tercantum dalam standar isi (SI) dan kurikulum 2013. Tujuan utama pembelajaran matematika di sekolah adalah agar siswa memiliki kemampuan matematis yang memadai untuk melanjutkan pendidikan ke jenjang yang lebih tinggi dan untuk menyelesaikan masalah dalam kehidupan sehari-hari (Fauzan, 2013). Kemampuan komunikasi matematis merupakan salah satu kemampuan yang penting dikarenakan melalui pengembangan kemampuan komunikasi matematis peserta didik akan mampu mempertajam cara berpikir sehingga meningkatkan kemampuan melihat keterkaitan antar konten matematika, mengembangkan pemecahan masalah, meningkatkan penalaran, menumbuh kembangkan diri, serta meningkatkan keterampilan sosial, dan menumbuh kembangkan kemampuan berpikir kritis, rasional, pemecahan masalah, dan keterampilan dalam bersosialisasi melalui writing and Talking (Rahmatina, 2016). Menulis merupakan alat bagi peserta didik yang tidak memiliki keberanian dalam berpendapat secara langsung, Sebagaimana yang disampaikan oleh, bahwa "writing as a communication tool for lowachieving students"(Baxter, Woodward, $\&$ Olson, 2005). Menurut Borasi dan Rose (1989) menyatakan "student who write to explain solution strategies experience an improvement in their problem solving skills". Jurdak dan Abu
Zein (1998) serta Kenney (2005) juga menyatakan "writing abut mathematics also generates benefits to understanding" (Kosko \& Wilkins, 2006). Berdasarkan beberapa sumber di atas dapat disimpulkan bahwa menulis untuk mengkomunikasikan solusi dari permasalahan yang diberikan merupakan cara terbaik untuk meningkatkan kemampuan pemecahan masalah matematis peserta didik.

Menurut Romberg dan Chair dalam Hodiyanto, komunikasi matematik yaitu menghubungkan benda nyata, gambar, diagram ke dalam idea matematika; menjelaskan idea, situasi dan relasi matematik secara lisan atau tulisan dengan benda nyatam gambar, grafik, dan aljabar; menyatakan peristiwa sehari-hari dalam bahasa atau simbol matematika; mendengarkan berdiskusi, dan menulis tentang matematika; membaca dengan pemahaman suatu persentasi matematika tertulis, membuat konjektur, menyusun argumen, merumuskan definisi dan generalisasai; menjelaskan dan membuat pertanyaan tentang matematika yang telah dipelajari (Hodiyanto, 2017). Berdasarkan pengertian yang luas dari Romberg dan Chair tersebut dan disampaikan juga oleh beberapa pakar, serta kementrian Pendidikan Ontario tahun 2005, indikator komunikasi matematis terdiri dari tiga aspek yaitu Written text, yaitu memberikan jawaban dengan menggunakan bahasa sendiri, membuat model situasi atau persoalan menggunakan lisan, tulisan, konkret, grafik, dan aljabar, menjelaskan dan membuat pertanyaan tentang matematika 


\section{JIPM (Jurnal Ilmiah Pendidikan Matematika), 7(1), September 2018- 51}

Zulfah, Wida Rianti

yang telah dipelajari, mendengarkan, mendiskusikan, dan menulis tentang matematika, membuat konjektur, menyusun argumen dan generalisasi; Drawing, yaitu merefleksikan benda-benda nyata, gambar, dan diagram ke dalam ide-ide matematika; Mathematical Expressions, yaitu mengekspresikan konsep matematika dengan menyatakan peristiwa sehari-hari dalam bahasa atau simbol matematika $(\mathrm{H}$, Hendriana, E, E Rohaeti, U, 2017) dan(Purwati \& Nugroho, 2009).

Penilaian kemampuan komunikasi matematis peserta didik dapat dilaksanakan melalui pemberian tes atau soal. Salah satu tes atau soal yang dapat digunakan untuk menganalisis kemampuan komunikasi matematis adalah dengan menggunakan soal PISA. PISA atau Program International Student Assessment adalah studi tentang program penilaian peserta didik tingkat internasional yang diselenggarakan oleh Organisation For Economic Co-Operation and Development (OECD). PISA merupakan upaya yang dilaksanakan untuk melihat sejauh mana program pendidikan negara berkembang dibanding dengan negara-negara lain di dunia(OECD, 2016). Hal ini menjadi sangat penting untuk melihat sejauh mana kemampuan anak-anak Indonesia dimasa akan datang mampu bersaing dengan anak-anak dari negara lain pada era globalisasi. Sebagai contoh Swiss dan Jerman yang melakukan reformasi kebijakan pendidikan yang signifikan setelah dirilisnya hasil penilaian peserta didiknya melalui PISA (Lusardi, 2015). Indonesia perlu menjadikan hasil PISA sebagai dasar dalam melakukan perbaikan terhadap dunia pendidikan sebagaimana yang dilakukan negara-negara maju tersebut. Tujuan PISA dalam bidang matematika yaitu untuk mengukur tingkat kemampuan peserta didik dalam menggunakan pengetahuan dan keterampilan matematika dalam menangani masalah kehidupan sehari-hari. Berdasarkan penjelasan tersebut, maka penulis menggunakan soal PISA 2015 dalam menganalisis kemampuan komunikasi matematis peserta didik Bangkinang. Sehingga peneliti melaksanakan penelitian dengan judul "Kemampuan Komunikasi Matematis Peserta Didik SMP Bangkinang dalam Menyelesaikan Soal PISA 2015", dengan tujuan untuk menganalisis kemampuan komunikasi matematis peserta didik Bangkinang melalui penyelesaian soal PISA 2015.

\section{METODE}

Penelitian ini merupakan penelitian deskriptif. Peneliti tidak melakukan perbandingan variabel pada sampel yang lain, dan tidak mencari hubungan variabel berupa komunikasi matematis dengan variabel yang lain. Analisis data dilakukan dengan cara mendeskripsikan atau menggambarkan data yang telah terkumpul sebagaimana adanya tanpa bermaksud tanpa membuat kesimpulan yang berlaku untuk umum atau generalisasi (Sugiyono, 2010). Pada penelitian ini data diperoleh melalui tes berupa soal PISA 2015 dan wawancara langsung kepada subjek yang diteliti untuk memperkuat data-data yang diperoleh. Soal PISA 2015 yang dimasukkan ke dalam kriteria soal komunikasi matematis yaitu soal nomor $2,12,14,15,29,30,31,38,42$, 43, 44, dan 46. Subjek penelitian yaitu peserta didik kelas VIII SMP Negeri 1 Bangkinang kota dan SMP Negeri 2 Bangkinang Kota pada semester genap tahun ajaran 2017/2018 berjumlah 39 orang. 


\section{HASIL DAN PEMBAHASAN}

\section{Analisis Soal No 2}

Soal No 2 merupakan soal pada kategori written text. Pada aspek written text memiliki indikator yaitu menunjukkan pemahaman terhadap konsep, membuat konjektur dan argumen, komputasi, dan membuat diagram, tabel, dan grafik. Berdasarkan analisis jawaban dari 39 orang peserta didik, diperoleh 22 orang

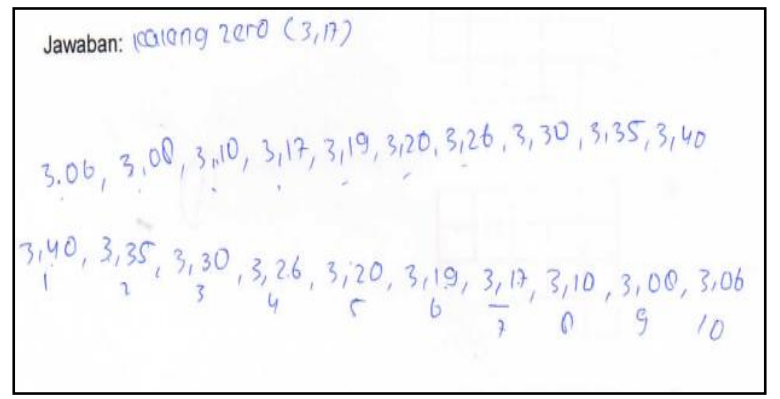

Gambar 1.a

Berdasarkan Gambar 1.a dan 1.b terlihat bahwa peserta didik memiliki cara berbeda dalam meyajikan jawabannya, namun memiliki tujuan yang sama yaitu menentukan urutan ketujuh, jika ukuran berat kaleng diurutkan dari terbesar ke terkecil.

\section{Analisis Soal No 12}

Soal No 12, dikategorikan ke dalam mathematical Expression yang memiliki indikator yaitu membuat model matematika, menggunakan dan membuat strategi agar memenuhi pemecahan masalah yang diinginkan, dan menuliskan perhitungan dengan benar. Berdasarkan jawaban dari peserta didik memperoleh skor tertinggi yaitu 4, 2 orang peserta didik memperoleh nilai dengan kriteria sedang antara $2-3$, dan 15 orang peserta didik memperoleh kriteria rendah dengan nilai antara $0-1$. Rata-rata kesalahan yang dilakukan oleh 15 orang peserta didik tersebut adalah mengambil kesimpulan yang salah, dan salah dalam menyusun tabel, yaitu peserta didik membuat ukuran berat dari terkecil ke terbesar.

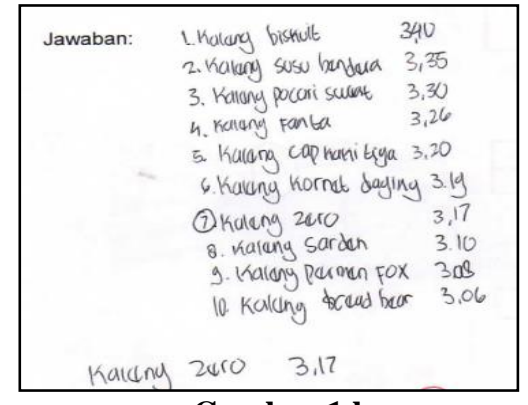

Gambar 1.b

39 orang peserta didik, 6 orang peserta didik berada pada kriteria kemampuan tinggi yaitu dengan skor 3, 6 orang peserta didik berada pada kategori sedang yaitu skor 2, dan 27 orang peserta didik berada pada kategori rendah yaitu antara 0 - 1. Pada soal no 12, rata-rata peserta didik banyak yang tidak menuliskan jawabannya. Berdasarkan wawancara yang dilakukan, peserta didik tidak memahami materi terkait sudut. Peserta didik tidak mengetahui prinsip dari sudut berpelurus yang merupakan kunci untuk memperoleh sudut-sudut yang ditanya.

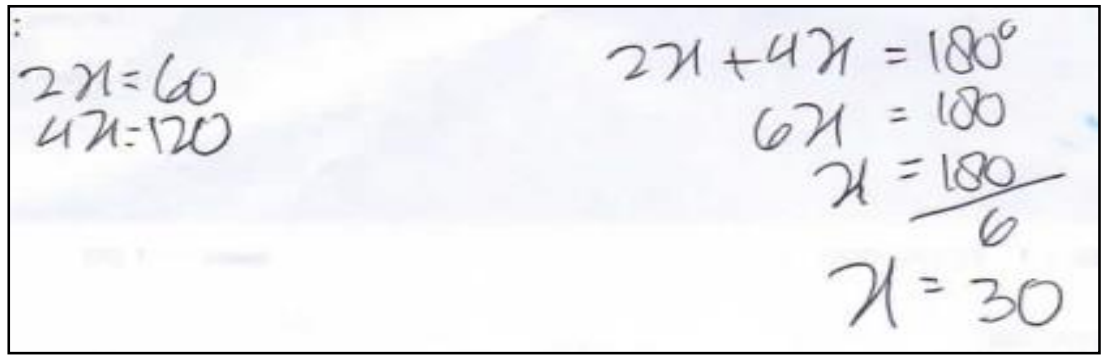

Gambar 2 


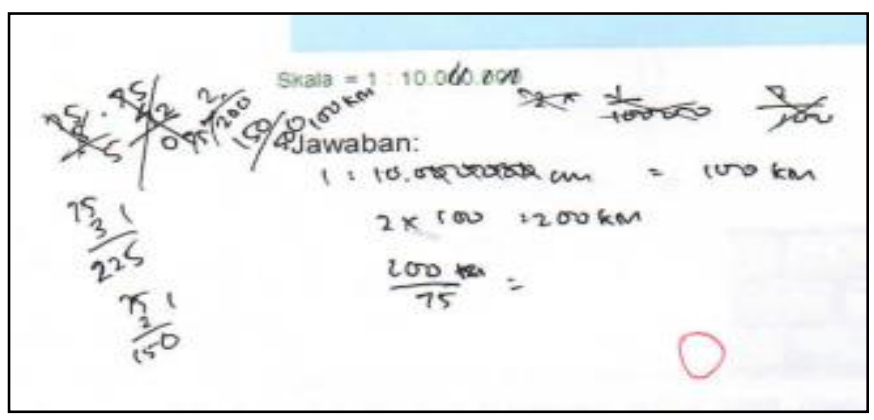

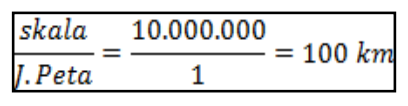

Gambar 2.b

Gambar 2.a

Berdasarkan Gambar 2.a terlihat bahwa peserta didik sudah memberikan model matematika dengan benar, yaitu menuliskan $2 x+4 x=180^{\circ}$ yang merupakan sudut berpelurus. Selajutnya peserta didik menggunakan komputasi dengan benar dan memperoleh nilai $x=30^{\circ}$. Sebagian besar peserta didik, tidak sampai kepada pertanyaan akhir yaitu menentukan jenis dari segitiga yang terbentuk dari ketiga sudut yang telah diperoleh sebelumnya.

\section{Analisis Soal No 14}

Soal nomor 14 termasuk ke dalam kategori Mathematical Expression. Berdasarkan jawaban yang diberikan peserta didik, peserta didik kesulitan dalam memberikan jawaban atau kesulitan dalam mengkomunikasikan solusi dari permasalahan yang diberikan. Hampir sebagian besar yaitu 34 orang peserta didik mengalami miskonsepsi dan tidak mampu menjawab soal tersebut, 5 orang memperoleh skor sedang, dan tidak ada satupun peserta didik yang mampu menjawab dengan benar. Berdasarkan analisis jawaban dan wawancara dengan peserta didik, kesalahan besar yang terjadi yaitu peserta didik menganggap bahwa keterangan di bawah peta yaitu suatu garis memiliki panjang $1 \mathrm{~cm}$ sebagai panjang garis yang terletak pada peta.
Padahal garis tersebut dapat dijadikan alat untuk membantu peserta didik mengukur panjang garis yang terletak pada peta. Peserta didik juga memberikan model matematika yang tidak tepat, yaitu sebagai berikut. Berdasarkan penelitian yang dilakukan oleh Aminah disimpulkan bahwa kemampuan komunikasi matematis menghubungkan benda nyata, gambar dan diagram kedalam ide matematika tergolong rendah (Aminah, Wijaya, \& Yuspriyati, 2018).

\section{Analisis Soal No 15}

Soal No 15 merupakan soal pada kategori Written text, dimana peserta didik harus membuat konjektur, melakukan perhitungan dengan tepat, dan/atau membuat tabel dengan tepat. Berdasarkan jawaban yang diberikan, 4 orang peserta didik memperoleh nilai tinggi, 1 orang peserta didik memperoleh nilai sedang, dan 34 orang peserta didik memperoleh nilai rendah. Rata-rata peserta didik tidak mampu menuliskan argumen terhadap permasalahan yang diberikan. Berdasarkan wawancara yang diberikan, setelah dijelaskan tujuan dari soal tersebut, barulah peserta didik mencoba memberikan jawabannya, dan sebagai peserta didik hanya mampu memberikan $3-4$ kemungkinan pengambilan uang tersebut. Peserta didik juga mengakui bahwa mereka 


\section{JIPM (Jurnal Ilmiah Pendidikan Matematika), 7(1), September 2018- 54}

Zulfah, Wida Rianti

malas mencari banyaknya variasi dalam pengambilan uang tersebut.

\section{Analisis Soal No 30}

Soal No 30, peneliti kategorikan ke dalam kemampuan komunikasi berupa Drawing, dengan indikator yaitu kemampuan membuat gambar, diagram, dan tabel, serta merefleksikan gambar, diagram kedalam ide-ide matematika. Berdasarkan analisis jawaban diperoleh 32 orang peserta didik mampu merefleksikan diagram ke dalam ide matematika dan memperoleh jawaban yang tepat, dan 7 orang lainnya belum mampu merefleksikan diagram ke dalam ide matematika sehingga memperoleh jawaban yang belum tepat.

\section{Analisis Soal No 31}

Peneliti mengkategorikan soal No 31 sebagai soal yang meminta kemampuan Mathematical Expression. Berdasarkan jawaban yang diberikan, 15 orang peserta didik mampu menjawab soal dengan baik, dan 24 orang peserta didik tidak memberikan jawaban yang tepat.

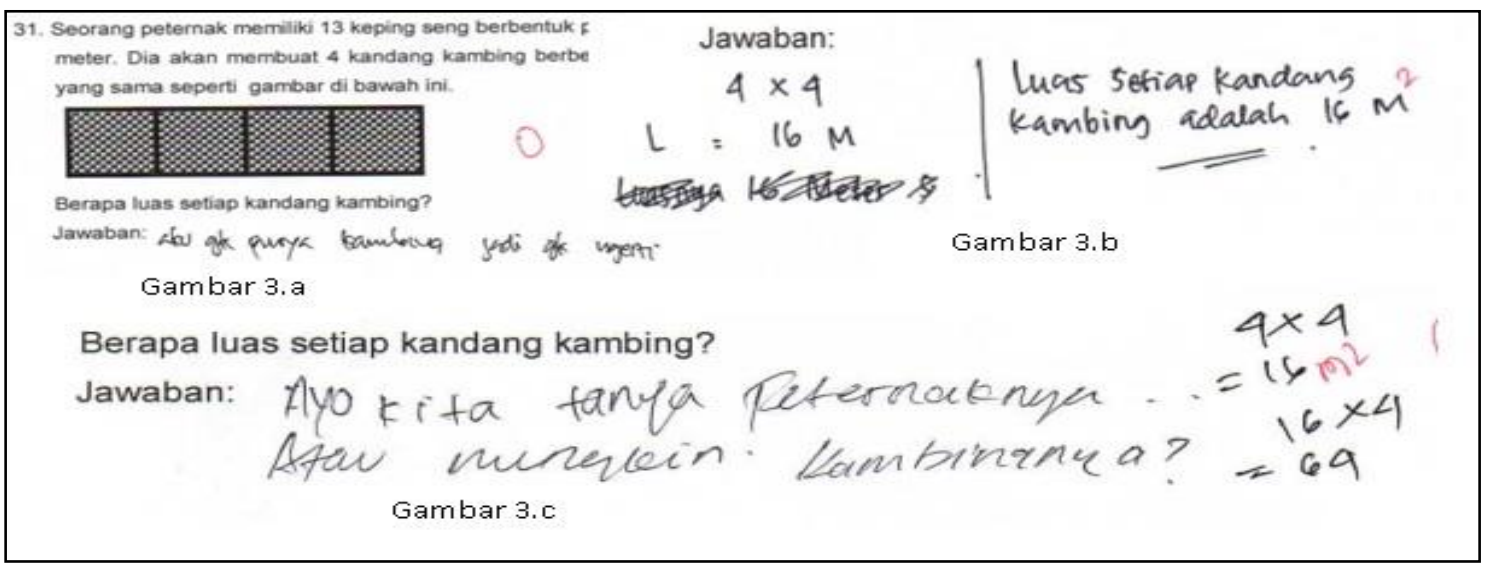

Berdasarkan Gambar 3.b; 3.d, sebagian besar yaitu 24 dari 39 orang terlihat bahwa peserta didik memberikan model matematika yang tepat, yaitu Luas satu kandang = sisi $\mathrm{x}$ sisi, namun peserta didik melupakan satuan yang harus diberikan untuk satuan luas. Namun pada Gambar 3.a, dan 3.c, peserta didik memberikan jawaban yang menunjukkan bahwa peserta didik tersebut tidak mampu menghargai kegunaan matematika dalam kehidupan sehari-hari yang merupakan tujuan dari pembelajaran matematika.

\section{Analisis Soal No 38}

Soal No 38 termasuk ke dalam kategori Drawing, yaitu merefleksikan gambar atau diagram ke dalam ide-ide matematika. Pada soal tersebut, hampir peserta didik tidak mampu merefleksikan grafik ke dalam ide matematika. Peserta didik kurang mampu membaca grafik yang disediakan di soal, sehingga peserta didik tidak bisa membuat ide matematika guna memperoleh jawaban yang diharapkan.

Ringkasan dari analisis ketujuh soal PISA 2015 yang dikategorikan soal Komunikasi Matematis yaitu (1) Written Text, Pada soal nomor 2; 56,4\% peserta didik berkemampuan rendah; $5,2 \%$ berkemampuan sedang; dan 38,4\% berkemampuan rendah. Pada soal nomor 15; $10,26 \%$ peserta didik berkemampuan tinggi; $2,56 \%$ berkemampuan sedang; dan $87,18 \%$ berkemampuan rendah. (2) Mathematical Expression, Pada soal 
nomor $12 ; 15,38 \%$ peserta didik berkemampuan tinggi; 15,38 peserta didik berkemampuan sedang; dan 69,24\% berkemampuan rendah. Pada soal nomor $14 ; 12,82 \%$ peserta didik berkemampuan sedang; dan $87,18 \%$ peserta didik berkemampuan rendah. Pada soal nomor 31; $38,46 \%$ berkemampuan sedang; dan $61,54 \%$ berkemampuan rendah. (3) Drawing, Pada soal nomor 30; 82,05\% peserta didik berkemampuan tinggi; dan $17,94 \%$ berkemampuan rendah. Pada soal nomor $38 ; 38,46 \%$ peserta didik berkemampuan sedang; dan $61,54 \%$ peserta didik berkemampuan rendah. Secara garis besar peserta didik masih lemah pada kategori mathematical expression. Hal ini perlu dilakukan penelitian lanjutan, agar diperolehnya kemampuan komunikasi matematis yang baik bagi seluruh peserta didik, karena berdasarkan penelitian yang dilakukan oleh Dwi bahwa informan yang memiliki kemampuan komunikasi matematis yang baik memiliki kemampuan berpikir dan keterampilan dalam proses pemecahan masalah matematika dengan sistematika yang benar dan strategi yang jelas(Erna, Umi, $\&$ Ari, 2017). Hal ini senada dengan pendapat Tinungki, 2015 yang menyatakan The mathematics communication ability is very important for the students so that they can solve mathematics problems by using good reasoning (Tinungki, 2015). Sehingga dapat disimpulkan memiliki

\section{DAFTAR PUSTAKA}

Aminah, S., Wijaya, T. T., \& Yuspriyati, D. (2018). Analisis Kemampuan Komunikasi Matematis Siswa Kelas VIII Pada Materi Himpunan, 1(1), 1522.

Baxter, J. A., Woodward, J., \& Olson, D. (2005). Writing in Mathematics: An kemampuan komunikasi matematis yang baik dapat membuat peserta didik memiliki keterampilan pemecahan masalah yang sistematis.

Guru juga harus terus meninjau kemampuan komunikasi matematis peserta didik. Guru dapat membuat jurnal untuk setiap siswanya, agar dapat memantau perkembangan kemampuan komunikasi matematis peserta didik, seperti yang disampaikan oleh Barter 2005, p 133 bahwa dengan membaca jurnal siswanya, guru menyadari manfaat yang tak terduga dari siswa yang menulis (Baxter et al., 2005), dalam artian menunjukkan kemampuan komunikasi matematis peserta didik melalui jurnal yang dibuat selama pembelajaran matematika satu semester.

\section{SIMPULAN}

Berdasarkan analisis data yang dilakukan pada 39 orang peserta didik dengan menyelesaikan soal PISA 2015 pada kategori soal komunikasi matematis, peserta didik masih lemah dalam membuat model matematika, menggunakan strategi yang sesuai sehingga dapat memenuhi kebutuhan pemecahan masalah. Pada bagian komputasi atau perhitungan sebagian besar peserta didik sudah memiliki kemampuan yang baik. Selanjutnya diikuti dengan rendahnya kemampuan merefleksikan grafik ke dalam ide-ide matematika.

Alternative Form of Communication for Academically Low-Achieving Students. Learning Disabilities Research and Practice, 20(2), 119-135. https://doi.org/10.1111/j.15405826.2005.00127.x

Erna, N. D., Umi, K. A., \& Ari, I. (2017). 
The Math Problem Solving Profile in Solve Linear Programming ' sProblem Based On Mathematic Communication Ability, 6(1), 53-59. Retrieved from http://journal.unipma.ac.id/index.php/ji pm JIPM

Fauzan, A. Y. (2013). Pengaruh Pendekatan RME dan Kemandirian Belajar Terhadap Kemamampuan Matematis Siswa. In Prosiding Semirata FMIPA Universitas Lampung (pp. 7-14).

H, Hendriana, E, E Rohaeti, U, S. (2017). Hard Skills dan Soft Skills Matematik Peserta Didik.

Hodiyanto. (2017). Kemampuan Komunikasi

Matematis Dalam Pembelajaran Program Studi Pendidikan Matematika Fakultas MIPATEK IKIP PGRI Pontianak Jalan Ampera No 8 Pontianak , Kalimantan Barat AdMathEdu | Vol . 7 No . 1 | Juni 2017 Kemampuan ... ( Hodiyanto ) Pendahuluan Manusia. AdMathEdu, 7(1), 8 .

Kosko, K. W., \& Wilkins, J. L. M. (2006). Mathematical Communication and Its Relation to the Frequency of Manipulative Use Karl W. Kosko \& Jesse L. M. Wilkins Virginia Polytechnic Institute \& State University. International Electronic Journal of Mathematics Education, 5(2), 79-90.
Lusardi, A. (2015). Financial Literacy Skills for the 21st Century: Evidence from PISA. Journal of Consumer Affairs, 49(3), 639-659. https://doi.org/10.1111 /joca.12099

OECD. (2016). Organisation for Economic Co-operation and Development (OECD). (2016). PISA 2015 results in focus.

Purwati, H., \& Nugroho, A. A. (2009). Analisis Kemampuan Komunikasi Matematis Mahasiswa Dalam Menyelesaikan Masalah Pada Mata Kuliah Program Linear. Jurnal Ilmiah Pendidikan Matematika, 1(2), 127-134. Rahmatina, D. (2016). Analisis Kemampuan Komunikasi Matematis Calon Guru Matematika Dalam Pemecahan Masalah Bangun Ruang Sisi Lengkung, 287-294.

Sugiyono. (2010). Metode Penelitian Pendidikan Pendekatan Kuantitatif, Kualitatif, dan $R \& D$.

Tinungki, G. M. (2015). The Role of Cooperative Learning Type Team Assisted Individualization to Improve the Students , Mathematics Communication Ability in the Subject of Probability Theory. Journal of Education and Practice, 6(32), 27-31 